\title{
Enhancement of biodiesel production from different species of algae
}

\author{
By Abd El-Moneim M. R. Afify, ${ }^{1}$ Emad A. Shalaby ${ }^{1 *}$ and Sanaa M. M. Shanab ${ }^{2}$ \\ ${ }^{1}$ Biochemistry Department, Faculty of Agriculture, Cairo University, Giza, Egypt, 12613 \\ ${ }^{2}$ Botany Department, Faculty of Science, Cairo University, Giza, Egypt, 12613.
}

( ${ }^{\star}$ Corresponding author: dremad2009@yahoo.com)

\begin{abstract}
RESUMEN
Mejora de la producción de biodiesel a partir de diferentes especies de algas.

Ocho especies de algas (4 Rhodo, 1 cloro y 1 macroalgas phaeophycean, 1 cianobacteria y 1 microalga verde) fueron utilizados para la producción de biodiesel utilizando dos sistemas de extracción con disolventes (hexano/éter $(1: 1, \mathrm{v} / \mathrm{v}))$ y (Cloroformo / metanol $(2: 1, v / v))$. La evaluación bioquímica de las especies de algas se llevó a cabo mediante la estimación de los porcentajes de biomasa, de lípidos, de biodiesel y de sedimento (glicerina y pigmentos). El sistema extracción con el disolvente hexano/éter $(1: 1, \mathrm{v} / \mathrm{v})$ produjo una bajada de los porcentaje de lípidos (2.3-3.5\% de peso seco), mientras que el sistema de extracción con el disolvente cloroformo/metanol $(2: 1, v / v)$ demostró ser más eficaz en la extracción de los lípidos y del biodiésel (2,5 - 12,5\% de peso seco) dependiendo de las especies de algas. Los extractos de microalgas verde Dictyochloropsis splendida produjeron los mayores porcentaje de lípidos y de biodiésel (12,5 y 8,75\%, respectivamente), seguida de la cianobacteria Spirulina platensis $(9,2$ y $7,5 \%$ respectivamente). Por otra parte, las macroalgas (rojo, marrón y verde) produce los porcentajes más bajos de biodiesel $(0,25-3,8 \%)$. Los ácidos grasos del biodiesel de Dictyochloropsis splendida Geitler se determinaron mediante cromatografía de gases. La producción de lípidos, de glicerol y de biodiesel con microalga verde Dictyochloropsis splendida Geitler (el alga más prometedora) fueron notablemente mejorada cuando se aumentó la concentración de sal o en ausencia de nitrógeno, durante su cultivo, con una producción máxima (26,8, 18,9 y 7,9\%, respectivamente) en ausencia de nitrógeno.
\end{abstract}

PALABRAS CLAVE: Biodiesel - Glicerina - Macroalgas - Microalgas - Lípidos totales

\section{SUMMARY}

Enhancement of biodiesel production from different species of algae.

Eight algal species (4 Rhodo, 1 chloro and 1 phaeophycean macroalgae, 1 cyanobacterium and 1 green microalga) were used for the production of biodiesel using two extraction solvent systems (Hexane/ether (1:1, v/v)) and (Chloroform/ methanol $(2: 1, \mathrm{v} / \mathrm{v}))$. Biochemical evaluations of algal species were carried out by estimating biomass, lipid, biodiesel and sediment (glycerin and pigments) percentages. Hexane/ ether $(1: 1, v / v)$ extraction solvent system resulted in low lipid recoveries (2.3-3.5\% dry weight) while; chloroform/methanol $(2: 1, v / v)$ extraction solvent system was proved to be more efficient for lipid and biodiesel extraction $(2.5-12.5 \%$ dry weight) depending on algal species. The green microalga Dictyochloropsis splendida extract produced the highest lipid and biodiesel yield (12.5 and $8.75 \%$ respectively) followed by the cyanobacterium Spirulina platensis $(9.2$ and $7.5 \%$ respectively). On the other hand, the macroalgae (red, brown and green) produced the lowest biodiesel yield. The fatty acids of Dictyochloropsis splendida Geitler biodiesel were determined using gas liquid chromatography. Lipids, biodiesel and glycerol production of Dictyochloropsis splendida Geitler (the promising alga) were markedly enhanced by either increasing salt concentration or by nitrogen deficiency with maximum production of $(26.8,18.9$ and $7.9 \%$ respectively) at nitrogen starvation condition.

KEY-WORDS: Biodiesel - Glycerin - Macroalgae Microalgae - Total lipid.

\section{INTRODUCTION}

The basic sources of energy are petroleum, natural gas, coal, hydroelectrical and nuclear. The need of energy is increasing continuously due to the increase in population and industrialization. The continued use of petroleum sourced fuels is now widely recognized as unsustainable because of the depletion supplies and the contribution of these fuels to the accumulation of carbon dioxide in the environment leading to increase of global warming. In the last ten years, many studies have been conducted on biofuels for substituting fossil fuels and reduce the greenhouse gas emission (Bastianoni et al., 2008). Biodiesel from oil crops, waste cooking oil and animal fat cannot realistically satisfy even a small fraction of the existing demand for transport fuels. Recent researches involved not only the existing renewable sources available from land plants, but also those coming from aquatic systems. Algae (macro and micro) have been taken in consideration as a residual biomass ready to be used for energy purposes. Algae, especially microalgae, were found to be the only source of renewable biodiesel that is capable of meeting the global demand for transport fuels (Chisti, 2007 and 2008). The idea of using algae as a source of fuel is not new (Chisti, 1980 - 1981; Nagle and Lemke, 1990; Sawayama et al., 1995), but it is now being taken seriously because of the increasing price of petroleum and more significantly, the emerging concern about global warming that is associated with burning fossil fuels (Gavrilescu and Chisti, 2005). Microalgae can provide several different types of 
renewable biofuels which include, methane, biodiesel (methyl esters) and biohydrogen (Gavrilescu and Chisti, 2005; Kapdan and Kargi, 2006; Spolaore et al., 2006). Oil productivity of many microalgae greatly exceeds the oil productivity of the best producing oil crops (Shay, 1993).

This work aimed to investigate, estimate and compare the potentiality and sustainability of the use of different algal species belonging to different divisions (macro and microalgae and cyanobacterium) for biodiesel production, using two different extraction solvent systems and comparing the biodiesel content produced by each algal species in both systems. Then, increase biodiesel production from the promising alga using salt stress and nitrogen deficiency conditions.

\section{MATERIALS AND METHODS}

\subsection{Chemicals and reagents}

Pure hexane, chloroform, ethanol, ether, acetone and methanol were purchased from E.Merch Co. (Germany), and distilled before use.

\subsection{Algal samples}

\section{Macroalgal collection}

Four red macroalgal species were used in this investigation: Jania rubens (L) lamouroux (Intertidal zone, 5-8 cm), Galaxaura oblongata (Ellis et solander) lamouroux (Intertidal zone, 8-11 cm), Gelidium latifolium (Grev.) Bornet ex Bornet et Thuret (intertidal zone, 5-10 cm), were collected from the Mediterranean sea at Abu Quir beach, Alexandria, Egypt, during summer season (July, 2009), while Asparagopsis taxiformis (Delile) Trevisan (Supralitoral and intertidal zones, 10-19 cm) was collected from El Garam beach, Marsa Matrouh, Egypt, during spring season (April, 2009). Another two macroalgal species, the green Ulva lactuca Linnaeus (Intertidal zone, $10-20 \mathrm{~cm}$ ) and the brown Colpomenia sinuosa (Mertens ex Roth) Derbes et Solier (Intertidal zone, 11-19 cm) species were collected from Abu Quir beach, Alexandria, Egypt, during summer season (July, 2009).

The collected algal species (4 red, 1 green and 1 brown macroalgae) once returned to the laboratory (Botany Depart. Fac. of Science, Cairo Univ.) were cleaned from sand and epiphytes, washed with fresh water then air dried, ground and kept in labeled glass bottles till use.

\section{Microalgal cultures}

One green microalga, Dictyochloropsis splendida Geitler, was isolated from Ain Helwan, Cairo, Egypt, during spring season (March, 2009), identified by Prof. Dr. Sanaa M. M. Shanab, Botany Department, Faculty of Science, Cairo University and cultured on Bold's basal medium (Bischoff and Bold, 1963) at $20^{\circ} \mathrm{C}$ under $16 / 8$ light/dark cycles and light intensity of $40 \mu \mathrm{E} / \mathrm{m}^{2} / \mathrm{s}$. The cyanobacterium, Spirulina platensis (Setch. et Gard) Geitler, was cultured on Zarrouk medium (Zarrouk, 1966) and obtained from the Culture Collection of Botany Department, Faculty of Science, Cairo University, Egypt.

Each microalgal species was harvested at the stationary phase (22 day for Dictyochloropsis splendida and 25 day for Spirulina platensis ) by centrifugation (3000 rpm) pellets were finally dried at $60^{\circ} \mathrm{C}$ for 20 min before extraction

\subsection{Stress conditions}

Dictyochloropsis splendida Geitler was cultured on Bolds basal medium (Bischoff and Bold, 1963) containing different salt concentrations $(2.5,5,7.5$ and $10 \mathrm{~g} / \mathrm{l})$ and nitrate concentrations $(25,12.5$, 6.25 and $0.0 \mathrm{~g} / \mathrm{l})$. A volume of $10 \mathrm{ml}$ of concentrated algal suspension was mixed with $90 \mathrm{ml}$ of culture media containing sodium chloride or nitrate concentrations. Algal cultures were aerated and incubated at optimal growth conditions (16-8 light/ dark cycles, light intensity of $40 \mu \mathrm{E} / \mathrm{m}^{2} / \mathrm{s}$ at $20 \pm 1^{\circ} \mathrm{C}$ ) for 22 days. The harvested alga was centrifuge, filtered and dried at low temp. (Less than $60^{\circ} \mathrm{C}$ ) to release water content.

\subsection{Algal growth rate}

The growth rate of the alga under different salt and nitrate concentrations were determined as chlorophyll and carotenoids content $(\mathrm{mg} / \mathrm{g}$ dry weight) using the method described by Holden (1965). In briefly, the fresh sample (1.0 g) was grinded in a mortar with acetone $(80 \%)$ in presence of calcium carbonate $(0.1 \mathrm{~g})$. The residue was reextracted for several times with acetone, until the solvents were colorless. The combined extract and washings were made up to a known volume (25 $\mathrm{ml}$ ) and the absorbance was measured at 663, 645 and $452 \mathrm{~nm}$ in $1 \mathrm{~cm}$ quartz cell, against blank (80\% aqueous acetone).

\subsection{Extraction of oil}

Extraction of oil was carried out using two extraction solvent systems to compare the oil content in each case and select the most suitable solvent system for the highest biodiesel yield.

\section{Chloroform /methanol (2:1, v/v) method}

A known weight of each ground dried algal species (10 $\mathrm{g}$ dry weight) was mixed separately with the extraction solvent mixture; chloroform/methanol $(100 \mathrm{ml}, 2: 1, \mathrm{v} / \mathrm{v})$ for $20 \mathrm{~min}$. using shaker, followed by the addition of mixture of chloroform/water (50 $\mathrm{ml}, 1: 1, \mathrm{v} / \mathrm{v}$ ) for $10 \mathrm{~min}$. filter and the algal residue was extracted three times by $100 \mathrm{ml}$ chloroform followed by filtration (Fig.1) according to Bligh and Dayer (1959). 


\section{Hexane/ether $(1: 1, v / v)$ method}

A known weight of each ground dried algal species (10 $\mathrm{g}$ dry weight) was mixed with the extraction solvent mixture, hexane/ether $(100 \mathrm{ml}$, $1: 1, \mathrm{v} / \mathrm{v})$, kept to settle for $24 \mathrm{hrs}$, followed by filtration (Fig. 1) according to Hossain and Salleh (2008).

\subsection{Transesterification and biodiesel production}

The extracted oil was evaporated under vaccum to release the solvent mixture solutions using rotary evaporator at $40-45{ }^{\circ} \mathrm{C}$. Then, the oil produced from each algal species was mixed with a mixture of catalyst $(0.25 \mathrm{~g} \mathrm{NaOH})$ and $24 \mathrm{ml}$ methanol (a process called transesterification, with stirring properly for $20 \mathrm{~min}$. The Mixture was kept for 3hrs in electric shaker at $3000 \mathrm{rpm}$. (National Biodiesel Board, 2002). After shaking the solution was kept for $16 \mathrm{hrs}$ to settle the biodiesel and the sediment layers clearly. The biodiesel layer was separated from sedimentation by flask separator carefully. Quantity of sediments (glycerin, pigments, etc) was measured. Biodiesel was washed by $5 \%$ water many times until it becomes clear then Biodiesel was dried by using dryer and finally kept under the running fan for $12 \mathrm{~h}$. the produced biodiesel was measured (using measuring cylinder), $\mathrm{pH}$ was recorded and stored for analysis.

\subsection{Analysis of fatty acids in the produced biodisel from Dictyochloropsis splendida Geitler using GLC}

The GLC analysis was carried out with a Pro-GC gas chromatography, with a dual flame ionization detector. The glass column $(1.5 \mathrm{~m} \times 4 \mathrm{~mm})$ was packed with $1 \% \mathrm{OV}-17$. Temperatures of injector and detector were $250^{\circ} \mathrm{C}$ and $300^{\circ} \mathrm{C}$, respectively. The column was hold at $200^{\circ} \mathrm{C}$ for $3 \mathrm{~min}$. then Programmed from 200 to $240^{\circ} \mathrm{C}$ (at rate of $10^{\circ} \mathrm{C} / \mathrm{min}$ ). Nitrogen was

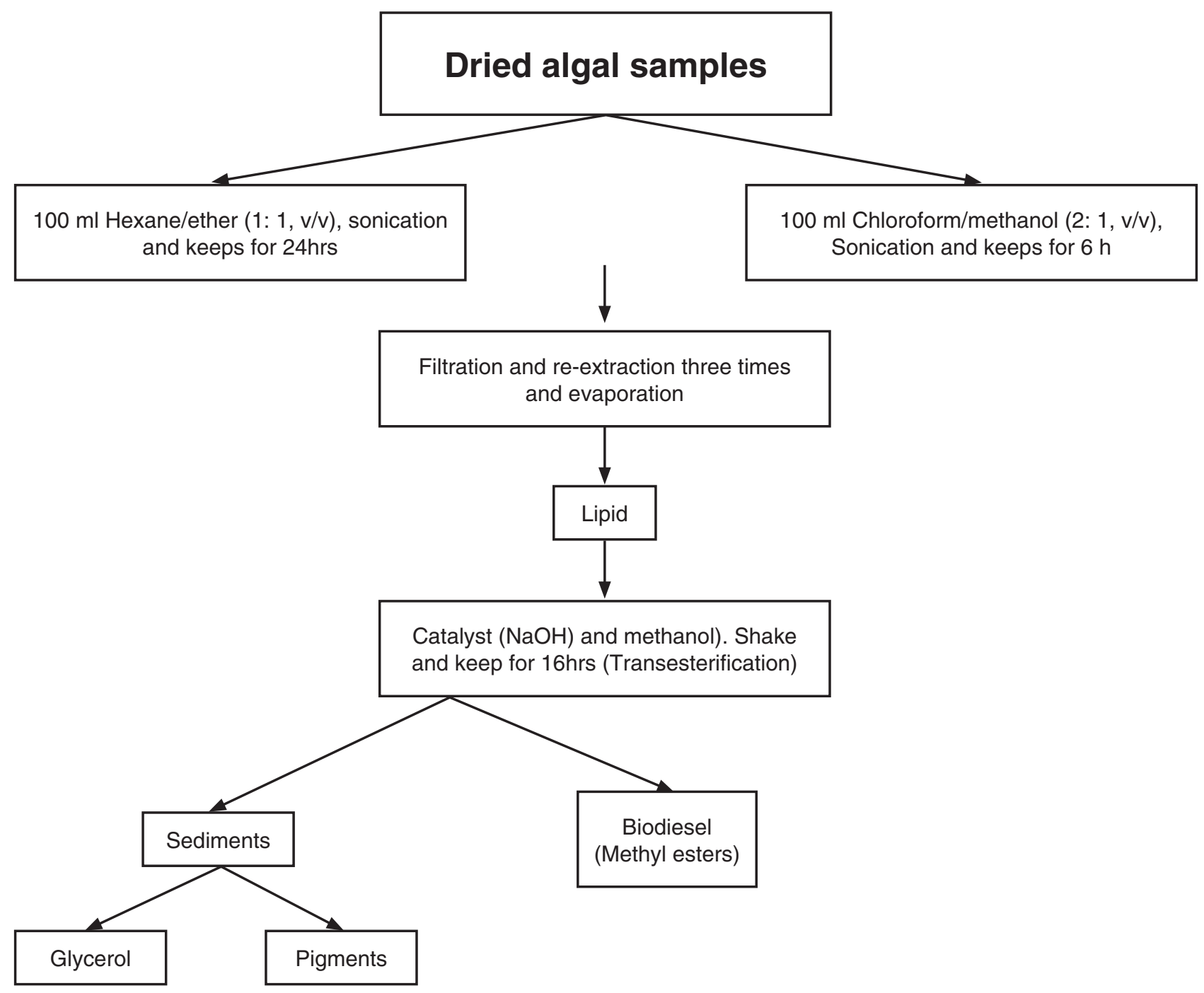

Figure 1.

Procedure (steps) of lipid and biodiesel production from algal sample using two solvent systems (hexane/ ether (1:1, v/v) and chloroform/ methanol $(2: 1, \mathrm{v} / \mathrm{v}))$. 
Table 1

Comparison between lipid percentages (\%) produced by eight algal species using hexane/ether $(1: 1, v / v)$ and chloroform/methanol $(2: 1, v / v)$ extraction systems.

\begin{tabular}{|c|c|c|}
\hline Algal species & $\begin{array}{c}\text { Chloroform/methanol } \\
(2: 1, v / v)\end{array}$ & $\begin{array}{c}\text { Hexane/ether } \\
(1: 1, v / v)\end{array}$ \\
\hline Jania rubens & $4.4 \pm 0.12$ & $2.8 \pm 0.04$ \\
\hline Galaxaura oblongata & $2.5 \pm 0.09$ & $2.4 \pm 0.01$ \\
\hline Gelidium latifolium & $3.0 \pm 0.0$ & $3.1 \pm 0.02$ \\
\hline Asporagopsis taxiformis & $4.1 \pm 0.08$ & $3.4 \pm 0.05$ \\
\hline Ulva lactuca & $4.2 \pm 0.1$ & $3.5 \pm 0.1$ \\
\hline Colpomenia sinuosa & $3.5 \pm 0.05$ & $2.3 \pm 0.03$ \\
\hline Dictyochloropsis splendida & $12.5 \pm 0.23$ & $2.4 \pm 0.14$ \\
\hline Spirulina platensis & $9.2 \pm 0.25$ & $3.0 \pm 0.10$ \\
\hline LSD & 0.3261 & 0.3261 \\
\hline
\end{tabular}

Each value is presented as mean of triplet treatments, LSD: Least significant difference at $P \leq 0.05$ according to Duncan's multiple range test.

Table 2

Total lipid, biodiesel, sediments percentage and biodiesel color of different algal species using the extraction solvent system Chloroform/methanol $(2: 1, \mathrm{v} / \mathrm{v})$

\begin{tabular}{lcccc}
\hline \multicolumn{1}{c}{ Algal sp. } & Lipid $\%$ & Biodiesel\% & Sediment $\%$ & Biodiesel color \\
\hline Jania rubens & $4.4 \pm 0.12$ & $0.25 \pm 0.01$ & $4.2^{\mathrm{a}} \pm 0.05$ & Light brown \\
Galaxaura oblongata & $2.5 \pm 0.09$ & $2.06 \pm 0.02$ & $0.08 \pm 0.0$ & Light green \\
Gelidium latifolium & $3.0 \pm 0.0$ & $1.3 \pm 0.0$ & $1.6 \pm 0.01$ & yellow \\
Asporagopsis taxiformis & $4.1 \pm 0.08$ & $3.64^{c} \pm 0.10$ & $0.40 \pm 0.01$ & Dark green \\
Ulva lactuca & $4.2 \pm 0.1$ & $3.8 \pm 0.12$ & $0.44 \pm 0.0$ & Light green \\
Colpomenia sinuosa & $3.5 \pm 0.05$ & $3.1 \pm 0.05$ & $0.31 \pm 0.05$ & yellow \\
Dictyochloropsis splendida & $12.5 \pm 0.23$ & $8.75 \pm 0.24$ & $3.75 \pm 0.08$ & colorless \\
Spirulina platensis & $9.2 \pm 0.25$ & $7.5 \pm 0.30$ & $1.66 \pm 0.06$ & Light green \\
LSD & 0.3261 & 0.3314 & 0.1786 & \\
\hline
\end{tabular}

Each value is presented as mean of triplet treatments, LSD: Least significant difference at $P \leq 0.05$ according to Duncan's multiple range test.

a carrier gas, hydrogen and air gases were used at flow rates of 30,33 and $330 \mathrm{ml} / \mathrm{min}$, respectively. The identification of fatty acids was accomplished by comparing the peaks of retention times with those of the corresponding standards. The quantity of individual compounds was determined by comparing the produced peak area by known weight of the algal material with standard curve of the authentic substances which expressed the relation between the different concentrations and their peak area.

\subsection{Statistical analysis}

Data were subjected to an analysis of variance, and the means were compared using the Least Significant Difference (LSD) test at the 0.05 and 0.01 levels, as recommended by Snedecor and Cochran (1982).]

\section{RESULTS AND DISCUSSION}

Results in table 1 showed the lipid amounts extracted from eight algal species by the two extraction methods described in the experimental section. The red macroalga Jania rubens produced $2.8 \%$ lipid when extracted using hexane/ ether $(1: 1, v / v)$ system whereas the recovery was doubled $(4.4 \%)$ using the extraction system chloroform/ methanol $(2: 1, v / v)$, No significant difference in the total lipid content was obtained from the red algae Galaxaura and Gelidium using both systems for extraction (2.4, 3.1 and 2.5, 3.0 respectively). The red seaweed Asparagopsis taxiformis and the green Ulva lactuca produced 1.2 fold increase in extracted lipid percentages and the brown macroalga Colpomenia sinuosa, produced a 1.52-fold increase in lipids when extracted by chloroform/methanol $(2: 1, \mathrm{v} / \mathrm{v})$ system, 
Table 3

Pigments contents (Chlorophyll a, b and carotenoids) of Dictyochloropsis splendida cultivated under stress conditions of $\mathrm{NaCl}$, nitrogen depletion and starvation ( $\mathrm{mg} / \mathrm{g}$ fresh weight)

\begin{tabular}{lcccc}
\hline \multicolumn{1}{c}{ Sample culture conditions } & Chlorophyll b & Chlorophyll a & $\begin{array}{c}\text { Total } \\
\text { Chlorophyll }\end{array}$ & $\begin{array}{c}\text { Total } \\
\text { carotenoids }\end{array}$ \\
\hline Control $\left(2.5 \mathrm{~g} / \mathrm{l} \mathrm{NaCl}\right.$ and $\left.25 \mathrm{~g} / \mathrm{l} \mathrm{NaNO}_{3}\right)$ & $0.171 \pm 0.02$ & $11.84 \pm 0.07$ & 12.01 & $2.58 \pm 0.05$ \\
$\mathrm{NaCl}$ stress & & & & \\
$5 \mathrm{~g} / \mathrm{l}$ & $0.170 \pm 0.01$ & $11.30 \pm 0.06$ & 11.47 & $2.81 \pm 0.0$ \\
$7.5 \mathrm{~g} / \mathrm{l}$ & $0.150 \pm 0.01$ & $12.50 \pm 0.03$ & 12.65 & $2.30 \pm 0.01$ \\
$10 \mathrm{~g} / \mathrm{l}$ & $0.120 \pm 0.0$ & $10.40 \pm 0.05$ & 10.52 & $4.60 \pm 0.5$ \\
Nitrogen stress & & & 10.52 & $0.67 \pm 0.01$ \\
$12.5 \mathrm{~g} / \mathrm{l}$ & $0.120 \pm 0.02$ & $10.40 \pm 0.1$ & 6.09 & $0.57 \pm 0.02$ \\
$6.25 \mathrm{~g} / \mathrm{l}$ & $0.064 \pm 0.0$ & $6.03 \pm 0.11$ & 5.51 & $5.60 \pm 0.2$ \\
$0.0 \mathrm{~g} / \mathrm{l}$ & $0.08 \pm 0.0$ & $5.43 \pm 0.06$ & 0.4214 & 0.2241 \\
$\mathrm{LSD}$ & 0.0521 & 0.4321 & & \\
\hline
\end{tabular}

Each value is presented as mean of triplet treatments, LSD: Least different significantly at $\mathrm{P} \leq 0.05$ according to Duncan's multiple range test.

Table 4

Lipid, biodiesel and glycerol contents (\%) of the green microalga Dictyochloropsis splendida, ulticated under salt stress, nitrogen depletion and starvation conditions

\begin{tabular}{|c|c|c|c|c|}
\hline Sample culture conditions & $\begin{array}{l}\text { Lipid content } \\
\qquad(\%)\end{array}$ & $\begin{array}{c}\text { Biodiesel } \\
\text { content (\%) }\end{array}$ & $\begin{array}{c}\text { Glycerol+ } \\
\text { pigments } \\
\text { content (\%) }\end{array}$ & $\begin{array}{l}\text { Biodiesel } \\
\text { color }\end{array}$ \\
\hline Control $\left(2.5 \mathrm{~g} / \mathrm{l} \mathrm{NaCl}\right.$ and $\left.25 \mathrm{~g} / \mathrm{l} \mathrm{NaNO}_{3}\right)$ & $12.50 \pm 0.36$ & $8.75 \pm 0.25$ & $3.75 \pm 0.12$ & Colorless \\
\hline \multicolumn{5}{|l|}{$\mathrm{NaCl}$ stress } \\
\hline $5 \mathrm{~g} / \mathrm{l}$ & $14.50 \pm 1.2$ & $8.90 \pm 0.62$ & $5.60 \pm 0.18$ & Colorless \\
\hline $7.5 \mathrm{~g} / \mathrm{l}$ & $17.00 \pm 0.53$ & $11.94 \pm 0.98$ & $5.06 \pm 0.22$ & Light green \\
\hline $10 \mathrm{~g} / \mathrm{l}$ & $17.50 \pm 0.36$ & $11.38 \pm 0.80$ & $5.11 \pm 0.24$ & Light green \\
\hline \multicolumn{5}{|l|}{ Nitrogen stress } \\
\hline $12.5 \mathrm{~g} / \mathrm{l}$ & $15.40 \pm 2.10$ & $8.90 \pm 0.36$ & $6.50 \pm 0.30$ & Yellowish green \\
\hline $6.25 \mathrm{~g} / \mathrm{l}$ & $16.20 \pm 1.8$ & $10.01 \pm 1.0$ & $6.19 \pm 0.12$ & Light Yellow \\
\hline $0.0 \mathrm{~g} / \mathrm{l}$ & $26.80 \pm 2.12$ & $18.90 \pm 1.2$ & $7.9 \pm 0.50$ & Yellow \\
\hline LSD & 0.3643 & 0.1681 & 0.1431 & \\
\hline
\end{tabular}

Each value is presented as mean of triplet treatments, LSD: Least different significantly at $P \leq 0.05$ according to Duncan's multiple range test.

as illustrated clearly in tables 1 and 2 . Moreover, the microalga Dictyochloropsis splendida showed $2.4 \%$ of total lipid when extracted with hexane/ether (1:1, $\mathrm{v} / \mathrm{v})$ system, but on using chloroform/methanol (2:1, $\mathrm{v} / \mathrm{v}$ ) as extraction mixture, the percentage of total lipids increased 5.2 timed to reach $12.5 \%$ showing at the same time the highest biodiesel production $(8.75$ $\%$ ) of the eight algal species used in this investigation. The cyanbacterium Spirulina platensis produced a 3-folds increase in lipid content using the chloroform/ methanol-based method (tables 1 and 2)

The obtained results illustrated in tables 1 and 2 revealed that the solvent mixture hexane/ether was not the most suitable system for lipid biodiesel extraction from algae because these solvents were unable to extract polar lipids. On the contrary chloroform/ methanol system extracted greater percentage of lipid (non polar and polar lipids) and consequently to higher biodiesel yields by transesterification (Fig. 1, Table 1). The lowest biodiesel production was observed in the red seaweed Jania rubens $(0.25 \%)$ followed in ascending order by Gelidium latifolium (1.3\%), Galaxaura oblongata (2.06\%) and Asparagopsis taxiformis (3.64\%). While the green macroalga Ulva lactuca and the brown seaweed Colpomenia sinuosa produced comparable biodiesel percentages (3.8 and 
Table 5

Analysis of fatty acids of the obtained biodiesel from the promising green microalga Dictyochloropsis splendida using GLC

\begin{tabular}{|c|c|c|c|}
\hline \multirow[b]{2}{*}{ Fatty acids } & \multirow[b]{2}{*}{${ }^{\mathrm{a}} \mathrm{RT}$} & \multicolumn{2}{|c|}{ Fatty acids percentage } \\
\hline & & $\begin{array}{l}\text { Algae cultivated } \\
\text { under normal } \\
\text { conditions }\end{array}$ & $\begin{array}{l}\text { Algae cultivated } \\
\text { under free } \\
\text { nitrogen media }\end{array}$ \\
\hline C10:0 (Capric acid) & 1.223 & 0.0 & 1.26 \\
\hline C14:0 (Myristic acid) & 2.437 & 13.04 & 13.88 \\
\hline C16:0 (Palmitic acid) & 2.860 & 81.14 & 69.59 \\
\hline C17:0 (Margeric acid) & 3.240 & 1.01 & 1.21 \\
\hline C18:0 (stearic acid) & 4.335 & 0.0 & 0.38 \\
\hline C18:1 (Oleic acid) & 4.667 & 0.26 & 1.11 \\
\hline C18:2 (Linoleic acid) & 5.333 & 4.39 & 12.14 \\
\hline C18:3 (linolenic acid) & 6.948 & 0.15 & 0.42 \\
\hline Total saturated fatty acids & & 95.19 & 86.33 \\
\hline Total unsaturated fatty acids & & 4.81 & 13.67 \\
\hline TU/TS & & 0.05 & 0.16 \\
\hline
\end{tabular}

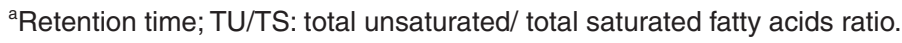

$3.1 \%$ respectively). The greatest yield of biodiesel was achieved by the green microalgae Dictyochloropsis splendida ( $8.75 \%)$ followed in descending order by the cyanbacterium Spirulina platensis $(7.5 \%)$ as illustrated in table 2. Using chloroform/methanol (2:1, v/v) solvent system we were able to produce not only biodiesel in large percentage but also a sediment containing glycerin and pigments, the produced biodiesel have slightly alkaline $\mathrm{pH}$ values ranged $7.5-8.5$ in all preparations. Our results, concerning the green microalga Dictyochloropsis splendida (produced 12.5\% lipids), agreed with those obtained by Hossain and Salleh (2008) who reported that the green filamentous alga Oedogonium sp produced higher lipid percentage $(9.2 \%)$ than Spirogyra sp (7.3\%). The highest biodiesel production from Dictyochloropsis splendida observed in this investigation was in good agreement with data reported by Chisti (2007 and 2008) who demonstrated that, the biodiesel from microalgae seems to be the only renewable biofuel that has the potential to completely displace petroleum derived transport fuels. The author added that oil productivity of many microalgae greatly exceeds the oil productivity of the best producing oil crops. The obtained data from the present investigation, using stressed culture conditions (salt stress, nitrogen depletion and starvation), illustrated that the microalgal growth, pigments production, lipid as well as biodiesel contents (Table 3 and 4) were affected. Table 3, showed that algal growth rate (under both salt concentrations and nitrate depletion) was inhibited by increasing salt concentration and decreasing nitrate ones.

It seemed that nitrate starvation $(0.0 \mathrm{~g} / \mathrm{l})$ produced the maximum decrease in algal growth represented as chlorophyll a content (mg/g dry weight). Also, chlorophyll b content was negativity affected by both stress conditions and the decrease in pigments contents under nitrate starvation was greater than those under salt stress conditions.

In both cases of stresses a remarkable increase in carotenoids contents were recorded at highest salt concentration $(10 \mathrm{~g} / \mathrm{l})$ and nitrate starvation $(0.0 \mathrm{~g} / \mathrm{l})$. These may be produced as a result of metabolic alteration under these stress conditions giving a protective means against the associated oxidative stress process which might occur. Under stress conditions. Generally, under both high salt conc. and nitrate starvation, the algal lipid contents were higher than in control conditions (under normal growth condition).

Maximum lipid and biodiesel contents were recorded in complete absence of nitrate (nitrate starvation) from the nutritive medium (26.8 and $18.9 \%$ respectively) as illustrated in Table 4 . These results may be explained by the fact that, under nitrate starvation, all the carbon structures produced during metabolic process might be directed towards lipid production which in turn converted to biodiesel by transesterification process. While in presence of nitrogen, most of the carbon structures was incorporated in nitrogenous compounds as amino acids, protein, nucleic acids or alkaloids. Under salt stress conditions (with normal nitrate conc. in culture media) the algal metabolism was altered with over production of carbon skeleton which were partly directed towards the production of substances with beneficial role in algal tolerance or defense mechanism as polyols, carbohydrate, methylated 
amino acids and protein in addition to the nitrogenous compounds and partly to form lipids and biodiesel. This explained the relatively lower lipid and biodiesel contents under salt stress conditions. The data obtained in this investigation were in good agreement with results published by Widjaja (2009) who reported that the green microalga Chlorella vulgaris accumulated high lipid content when cultivated in nitrogen depletion condition (0.02 mg/l nitrate). Our results also went parallel with those obtained by Lardon et al. (2009) who found that, the control of nitrogen stress during the culture and optimization of wet extraction led to maximum biodiesel production from the microalgal culture Chlorella vulgaris.

Analysis of the produced biodiesel from the promising alga Dictyochloropsis splendida (Table 5) showed that the unsaturated fatty acids percentage was increased in alga cultivated in nitrogen free media $(0.0 \mathrm{~g} / \mathrm{l} N)$ two times more than normal conditions (13.67, 4.81\% respectively). However, the composition of fatty acids were different in these cases depending on its growth condition as showed in Table 5. These results were in agreements with those reported by Wood (1974) relative to Chlorophycean species. Furthermore Ramos et al. (2009) reported that monounsaturated, polyunsaturated and saturated methyl esters were built in order to predict the critical parameters of European standard for any biodiesel, composition. The extent of unsaturation of microalgae oil and its content of fatty acids with more than four double bonds can be reduced easily by partial catalytic hydrogenation of the oil (Jang et al., 2005, Dijkstra, 2006). Concerning the fatty acids contents of the produced biodiesel from microalgae, Chisti (2007) reported in his review that, microalgal oils differ from vegetable oils in being quite rich in polyunsaturated fatty acids with four or more double bonds (Belarbi et al., 2000) as eicosapentanoic acid (C20:5n-3) and docosahexaenoic acid (C22:6n-3) which occurred commonly in algal oils. The author added that, fatty acids and fatty acid methyl esters with four and more double bonds are susceptible to oxidation during storage and this reduces their acceptability for use in biodiesel especially for vehicle use (European standard EN 14214 limits to 12\%) while no such limitation exists for biodiesel intended for use as heatling oil. In addition to the content of unsaturated fatty acids in the biodiesel also its iodine value (represented total unsaturation) must be taken in consideration (not exceeded $120 \mathrm{~g}$ iodine/100g biodiesel according to the European standard).

\section{REFERENCES}

Bastianoni S, Coppola F, Tiezzi E, Colacevich A, Borghini F, Focardi S. 2008. Biofuel potential production from the Orbetello lagoon macroalgae a comparison with Sunflower feedstock. Biomass and Bioenergy 10, 1-10.

Belarbi EH, Molina-Grima E, Chisti Y. 2000. A process for high yield and scaleable recovery of high purity eicosapentanoic acid esters from microalgae and fish oil. Enzyme Microb. Technolo. 26, 516-29.

Bischoff HW, Bold HC. 1963. Phycological studies. IV. Some algae from Enchanted Rock and related algal species. The Univ. of Texas pub. No 6318. 95

Bligh EG, Dayer WJ. 1959. A rapid method for total lipid extraction and purification. Can. J. Biochem and Physiol. 37, 911-7.

Chisti Y. 1980-1981. An unusual hydrocarbon. J. Ramsay Soc. 27-28, 24-6.

Chisti Y. 2007. Biodiesel from microalgae. Biotechnology Advances 25, 294-306.

Chisti Y. 2008. Biodiesel from microalgae beats bio-ethanol. Trends in Biotechn. 26, 126-31.

Dijkstra AJ. 2006. Revisiting the formation of trans isomers during partial hydrogenation of tricylglycerol oils. Eur. J. Lipid Sci. Technol. 108, 249-64.

Gavrilescu M, Chisti Y. 2005. Biotechnology a sustainable alternative for chemical industry. Biotechnol. Adv. 23, 471-9.

Holden M. 1965. Chlorophyll. In "chemistry and biochemistry of plant pigments". (Ed. Goodwin, T.W.). Academic Press, London. pp. 462-88.

Hossain ABM, Salleh A. 2008. Biodiesel fuel production from algae as renewable energy. Am. J. Biochem. and Biotechn. 4, 250-254.

Jang ES, Jung MY, Min DB. 2005. Hydrogenation for low trans and high conjugated fatty acids. Comp. Rev. Food Sci. 4, 22-30.

Kapdan I K, Kargi F. 2006. Bio-hydrogen production from waste materials. Enzyme Microb. Technol. 38, 569-82.

Lardon L, Helias AQ, Sialve B, Steyer J-P, Bernard O. 2009. Life-cycle assessement of biodiesel production from microalgae. Environ. Sci. Technol. 3, 1-6.

Nagle N, Lemke P. 1990. Production of methyl ester fuel from microalgae. Appl. Biochem. Biotechnol. 24-5, 335-61.

National Biodiesel Board. 2002. USA. Available in www. biodiesel.org/.

Ramos MJ, Fernández CM, Casas A, Rodríguez, L. Pérez A. 2009. Bioresource Technology 100, 261-8.

Sawayama S, Inoue S, Dote Y, Yokoyama SY. 1995. $\mathrm{CO}_{2}$ fixation and oil production through microalgae. Energy Convers Manag. 36, 729-31.

Shay EG. 1993. Diesel fuel from vegetable oils: status and opportunities. Biomass Bioenergy, 4: 227-42. http://dx.doi.org/10.1016/0961-9534(93)90080-N

Snedecor GW, Cochran WG. (1982). Statistical Methods. The lowa State Univ. Press., Ames., lowa, USA. 507 pp.

Spolaore P, Joannis-cassan C, Duran E, Isambert A. 2006. A commercial application of microalgae. J. Biosci. Bioeng. 101, 87-96.

Widjaja A. 2009. Lipid production from microalgae as a promising candidate for biodiesel production. Makara, Teknologia 13, 47-51.

Wood BJUB. 1974. Fatty acids and saponifiable lipids. Chapter (8) in: Stewart W. D. P (ED.). Algal Physiology and Biochemistry, 236-65.

Zarrouk C. 1966. Contribution a l'etude d' une cyanophyceae. Influence de divers facteurs physiques et chimiques sur la croissance et la photosynthese de Spirulina maxima (Setch. et Gardner) Geitler. Ph.D. Thesis, University of Paris, France. 